\title{
人工内リンパ中央階注入時の内・外リンパ圧
}

\author{
竹内 俊二・竹田 泰三・齋藤 春雄
}

\section{Pressure Relationship between Perilymph and Endolymph after the Infusion of Artificial Endolymph into Scala Media}

\author{
Shunji Takeuchi, Taizo Takeda and Haruo Saito \\ (Kochi Medical School)
}

The pressure difference between the perilymph and the endolymph following infusion of artificial endolymph into the endolymphatic space was studied in guinea pigs. The perilymphatic and the endolymphatic pressures were measured simultaneously with two sets of a servo-nulling system. Endolymphatic infusion caused pressure increases in both the endolymphatic and the perilymphatic spaces, but no significant pressure difference between them. Soon after the endolymphatic infusion, both pressures returned to nearly the initial levels. We conclude that the endolymphatic and the perilymphatic pressures are very closely related and there may not be a significant pressure difference between them in endolymphatic hydrops.

Key words : inner ear fluid pressures, simultaneous recording, hydrops

はじめに

内リンパ水腫においては，その形態学的特徵 から，内リンパ圧の上昇があるとする説がある. Tonndorf ${ }^{12)}$ は，内リンパ圧の上昇に基づいて メニエル病の難聴の 発生機序を説明した. Ito $ら^{3)}$, Bohmer $ら^{4)}$ は実験的内リンパ水腫動物の 内・外リンパ圧に有意の差を認めたと報告して いる. また Long $ら^{5)}$ も, 実験的内リンパ水腫 形成の初期において内・外リンパ圧に差がある と報告している。しかしながら我々の実験では， 内リンパ水腫モルモットの内・外リンパ圧の間 に有意の差がなかっだ 。 また，内・外リンパ 圧を同時に測定しながら無呼吸負荷やグリセロ 一ル負荷7), 脳脊䯣液腔の加圧 ${ }^{8)}$ を行った実験 でも，内・外リンパ圧の間に有意の差を生じな
かった.

内・外リンパの間に压差が生じうるかという 問題は, 内耳の病態生理, 特に内リンパ水腫に おける難聴やめまいの発生機序に関連して重要 である，本研究では，内リンパ水腫の内・外リ ンパ圧を更に詳細に検討するために，内・外リ ンパ圧を同時に測定しつつ，蝸牛中央階に人工 内リンパを微量注入して, 中央階の体積増加に よって内・外リンパ圧の間に差が生じるか否か を検討した. 注入後の膜迷路の形態的な変化に ついても検討した.

\section{方法}

実験系のブロックダイヤグラムを図 1 亿示す. 内・外リンパ圧の測定は，サーボ圧測定装置 (Micropressure system model 900, WPI Inc, 
New Haven, Conn, USA) を， 2 台同時に用い て行った． 2 台のシステムの較正の方法は，す でに報告した ${ }^{6)}$ 。 測定に用いたガラスマイクロ ピペットの先端は約 5 ミクロンに研磨し， $2 \mathrm{M}$ $\mathrm{KCl}$ を充填した。 内リンパ腔への刺入は，ピペ ット先端の電位を同時に測定し，EPを指標と して確認した。

内リンパ腔への人工内リンパの注入の為に図 2 に示す器具を自作した。 注入用ガラスマイク ロピペットの先端は20〜30ミクロンとした。内 リンパ腔への刺入は $\mathrm{EP}$ を同時に測定して確認 した。注入用ガラスマイクロピペット先端の電 位の測定には Dual Electrometer model 223 (WPI Inc, New Haven, Conn, USA) を用いた.

人工内リンパの組成を表 1 亿示す。乙れは Marcus ら ${ }^{9}$ の内リンパ腔灌流実験に基づいた あのであり，電解質濃度と浸透圧がよく考慮さ れている. Fernandez ${ }^{10)}$ の報告に基づいて計算 するとモルモットの中央階の体積は約 $2 \mu \mathrm{l}$ であ るので，注入量は中央階の十分な体積増加を起 こす量を考えて $2 \mu \mathrm{l}$ とした。注入用ピペットは 先端径が20〜30ミクロンと小さいため先端径の
わずかな違いが注入に対する抵抗の大きな差と なって現れる。乙のため, 微量注入器で同じよ うに加圧しても注入に要した時間は30秒から 4 分と差ができた。

実験には体重 250～300 g のプライエル反射 良好な白色モルモットを31匹用いた。乙のうち 26匹は圧の測定に，5 匹は組織学的検討に用い た。ペントバルビタール $25 \mathrm{mg} / \mathrm{kg}$ を腹腔内投 与して麻酔, 気管切開を行って人工呼吸器にて 維持, 臭化パンクロニウム $0.4 \mathrm{mg} / \mathrm{kg}$ を筋肉 内注射して不動化させた。

頭部を固定した後，側方から中耳骨胞を開放 し蝸牛を明視下に扮いた。内耳への影響を最小 限とするため，耳小骨は温存した。内リンパ压

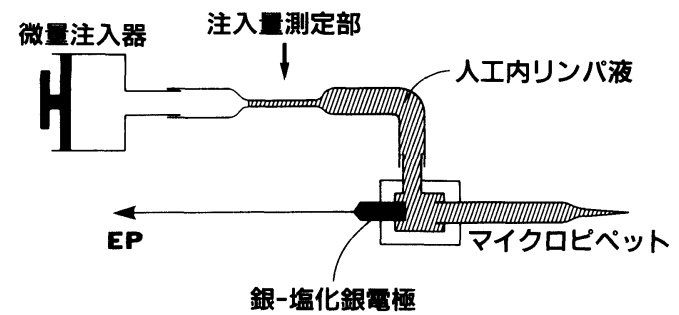

図 2 人工内リンパ液注入装置

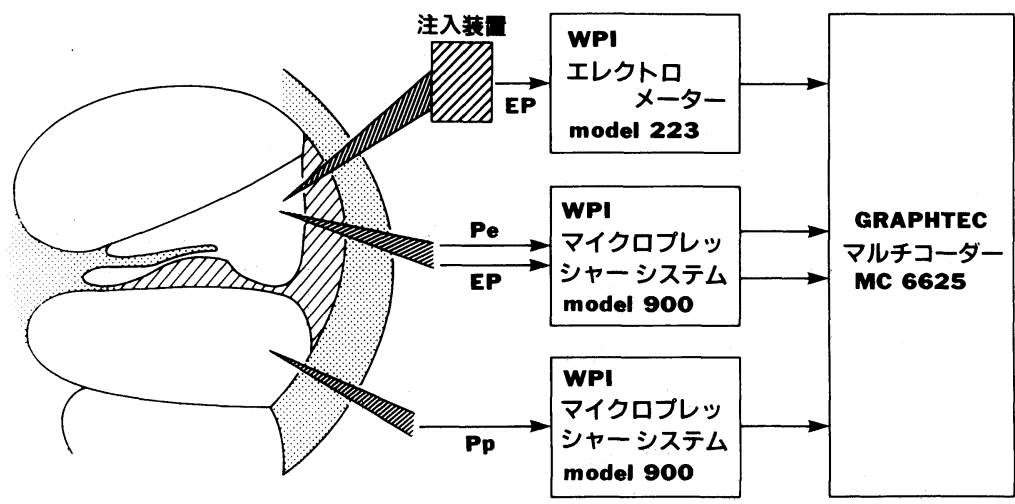

図 1 実験系のブロックダイヤグラム．外リンパ圧 $(\mathrm{Pp})$ と内リンパ圧 $(\mathrm{Pe})$ を同 時に測定し，人工内リンパ液を中央階に微量注入した。中央階への刺入は $\mathrm{EP}$ の同時測定によって確認した。

表 1 人工内リンパ液の組成

\begin{tabular}{|c|c|c|c|c|c|c|c|c|c|}
\hline 試 & 薬 & $\mathrm{KCl}$ & $\mathrm{NaCl}$ & $\mathrm{KHCO}_{3}$ & $\mathrm{MgCl}_{2}$ & $\mathrm{CaCl}_{2}$ & $\mathrm{~K}_{2} \mathrm{HPO}_{4}$ & $\mathrm{KH}_{2} \mathrm{PO}_{4}$ & mannitol \\
\hline 濃月 & M) & 126 & 1 & 25 & 0.025 & 0.025 & 1.8 & 1.4 & 25 \\
\hline
\end{tabular}


の測定には蝸牛基底回転中央階骨壁に，外リン パ压の測定には基底回転鼓室階骨壁に，それぞ れ直径約50ミクロンの小孔を開けて測定用のガ ラスマイクロピペットを刺入した。 内リンパ腔 注入用のガラスマイクロピペットは基底回転中 央階骨壁に圧測定用の小孔から約 $1.5 \mathrm{~mm}$ 離れ て小孔をあけて刺入した．圧測定用の 2 本，内 リンパ腔注入用の 1 本，計 3 本のピペット刺入 部は，歯科用セメント (Unident SMFP, 三金 社製）で，密閉，固定した.

内リンパ腔注入後の膜迷路の形態的な変化を 観察するため, $2 \mu \mathrm{l}$ 注入後, 生体灌流固定を行い 側頭骨を採取し，脱灰ののちセロイジン・パラ フィン重包埋法でブロックを作製し，薄切した。

\section{結 果}

圧測定に用いた26匹のモルモットのうち12匹 において，内・外リンパ圧の同時測定と内リン パ腔への注入が可能であった。 これ以外のモル
モットでは，圧測定用ピペットの破損や， EP が $60 \mathrm{mV}$ 以下であったため，結果の検討から 除外した.

正常モルモットの無負荷の状態では内・外り ンパ压に有意の差はなく7)，内・外リンパ圧の 絶対值は個体ごとに異なり，同一個体でも体位 によって変化するため，圧の絶対值ではなく圧 の変化について調べた.

㘡 3 に内リンパ腔へ人工内リンパを注入した 時の内・外リンパ压の変化の一例を示す.人 工内リンパの注入によって内・外リンパ圧共に 上昇したが，その変化はほぼ等しく，注入終了 後は両圧共に同じように低下した。12匹のモル モットにおいて，注入量が $0.5 \mu \mathrm{l}, 1.0 \mu \mathrm{l}, 2.0$ $\mu \mathrm{l}$ の各時点での内・外リンパ压差を表 2 に示 す．両圧の間に有意の差はなかった。

注入中ピペット周囲や蝸牛空からの明らかな 液の漏れはなく，注入後の注入ピペット内への
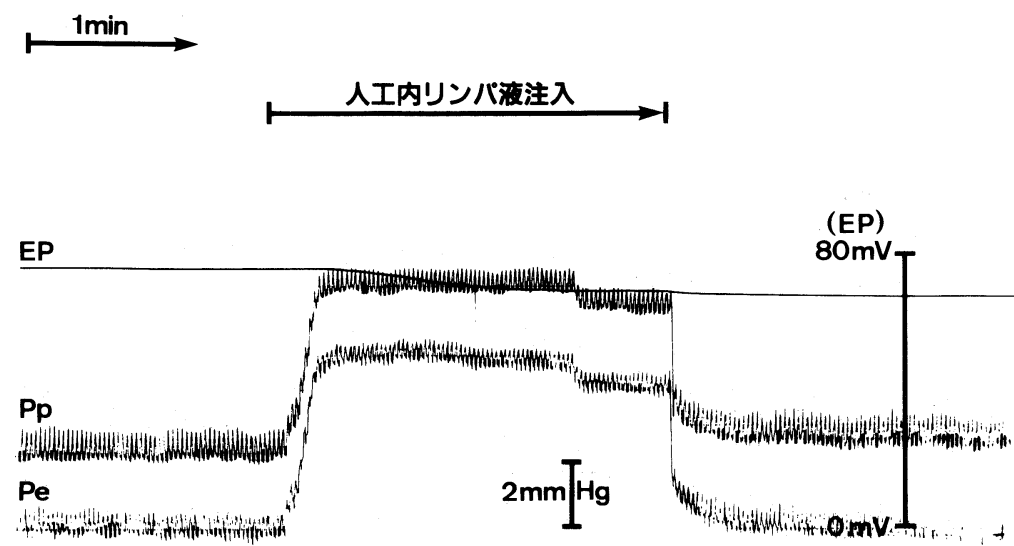

図 3 中央階へ人工内リンパ液を 2.01 注入した際の内リンパ圧 $(\mathrm{Pe})$, 外リンパ 圧 (Pp), EP の変化の一例（動物 No. 420).

表 2 中央階へ人工内リンパ液を注入した際の内リンパ圧 $(\mathrm{Pe})$ と外リンパ压 $(\mathrm{Pp})$ の差

\begin{tabular}{|c|c|c|c|c|c|c|c|c|c|c|c|c|c|c|}
\hline \multirow[t]{3}{*}{$\begin{array}{c}\text { 注入量 } \\
(\mu \mathrm{l})\end{array}$} & \multicolumn{12}{|c|}{$\begin{array}{l}\mathrm{Pe}-\mathrm{Pp} \\
(\mathrm{mmHg})\end{array}$} & \multicolumn{2}{|c|}{$\begin{array}{c}\mathrm{Pe}-\mathrm{Pp} \\
(\mathrm{mmHg})\end{array}$} \\
\hline & \multicolumn{12}{|c|}{ 動 物 番 号 } & \multirow{2}{*}{ 平 均 } & \multirow{2}{*}{ 標準偏差 } \\
\hline & 409 & 413 & 416 & 420 & 421 & 422 & 425 & 426 & 427 & 428 & 429 & 430 & & \\
\hline 0.5 & 0.0 & 0.0 & 0.0 & 0.0 & 0,0 & 0.0 & 0.1 & 0.0 & 0.0 & 0.1 & 0.0 & 0.0 & 0.017 & 0.037 \\
\hline 1.0 & 0.2 & -0.2 & -0.3 & 0.0 & 0.0 & 0.0 & 0.2 & 0.0 & 0.0 & 0.1 & 0.0 & 0.0 & 0.000 & 0.135 \\
\hline 2.0 & -0.2 & -0.2 & 0.0 & 0.0 & 0.0 & 0.0 & 0.0 & 0.2 & 0.2 & 0.2 & 0.0 & 0.0 & 0.017 & 0.128 \\
\hline
\end{tabular}


逆流もなかった。

注入中の圧上昇の最高值と, 注入後 1 分の圧 の值を表 3 に示す。外リンパ圧と内リンパ圧は ほぼ同様に変化したので内リンパ圧の変化のみ

表 3 人工内リンパ液注入による内リンパ压 $(\mathrm{Pe})$ の最高值之注入終了後 1 分の内リンパ压. 注入前の值を $0.0 \mathrm{mmHg}$ とした.

\begin{tabular}{|c|c|c|}
\hline 動 物 番 号 & $\begin{array}{c}\mathrm{Pe} \text { (最高值) } \\
\text { (mmHg) }\end{array}$ & $\begin{array}{c}\mathrm{Pe} \text { (注入後) } \\
(\mathrm{mmHg})\end{array}$ \\
\hline 409 & $>16.0$ & 0.4 \\
\hline 413 & $>16.0$ & 0.7 \\
\hline 416 & 5.2 & -0.2 \\
\hline 420 & 2.0 & 0.4 \\
\hline 421 & 1.8 & 0.6 \\
\hline 422 & 1.1 & 0.0 \\
\hline 425 & 1.5 & 0.3 \\
\hline 426 & 4.1 & 0.2 \\
\hline 427 & 3.2 & 0.3 \\
\hline 428 & 12.4 & 1.2 \\
\hline 429 & 11.8 & 0.6 \\
\hline 430 & 10.8 & 0.5 \\
\hline
\end{tabular}

を示した。注入終了後，圧はただちに低下しは じめ30秒から 1 分後には注入前の值に近づいた。

$2 \mu \mathrm{l}$ 注入後の蝸牛では, 組織学的にライスネ ル膜の軽度の伸展と球形囊の拡張がみられた (図 4).

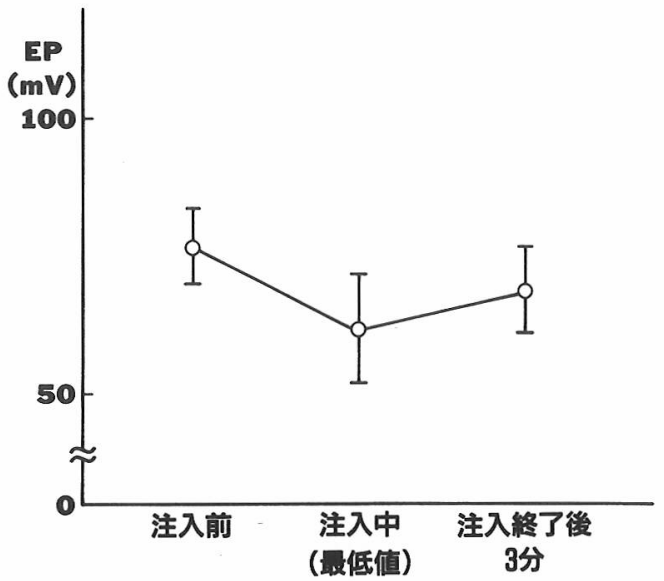

図 5 中央階へ人工内リンパ液を 2.01 注入した際の $\mathrm{EP}$ の変化. $\mathrm{n}=12$, 平均十標準偏差.

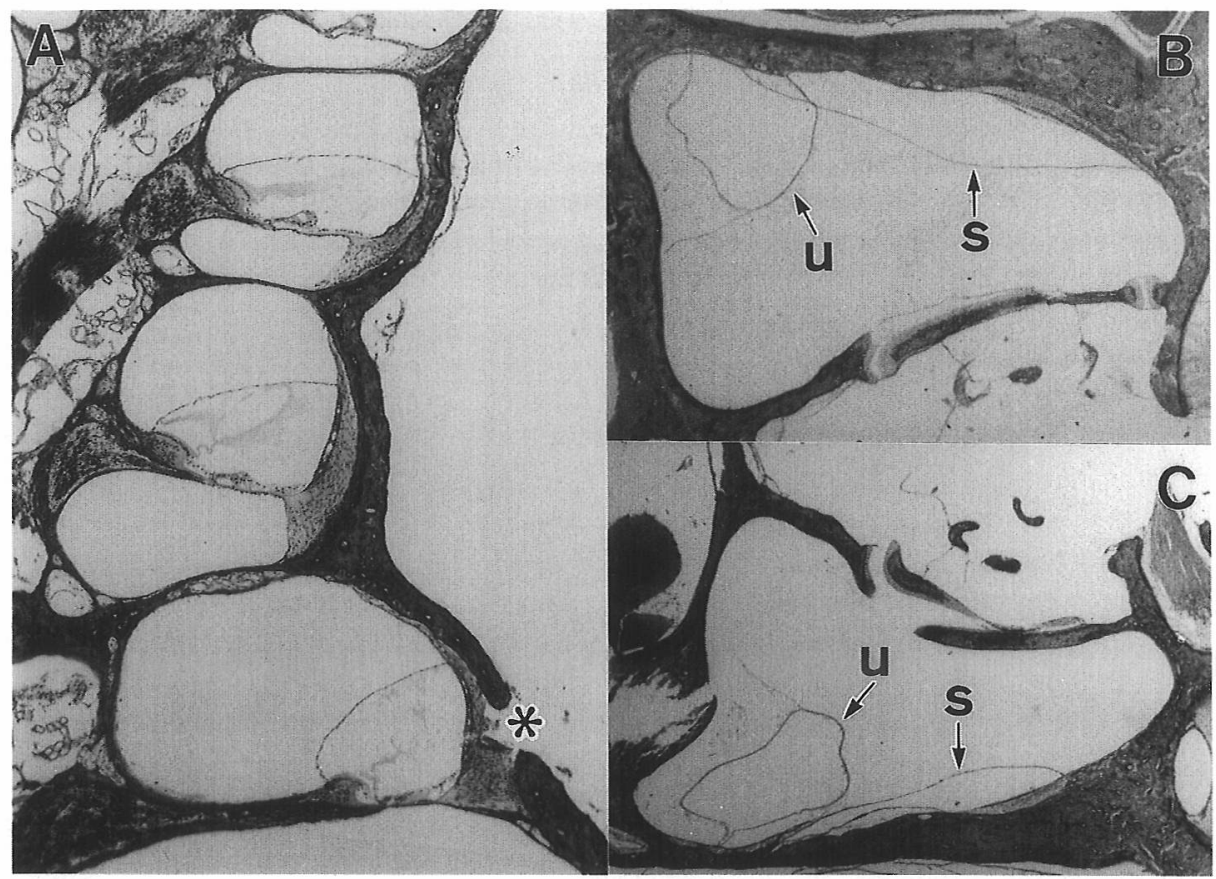

図 4 中央階へ人工内リンパ液を 2.01 注入した後の組織像. $\mathrm{A}$ ：蝸牛, B : 注入側の前庭, $\mathrm{C}$ : 正常側の前庭. ** ; ピペット刺入部, $\mathrm{s}$; 球形囊, $\mathrm{u}$; 卵形囊. 
EP は注入によって低下したが，注入後は回 復する傾向がみられた（図 5 ).

\section{考察}

本研究で用いた内リンパ腔へ人工内リンパを 微量注入する方法は，内リンパ腔の急激な体積 の増加を惹起する。乙れは注入後の組織標本で 伸展したライスネル膜と拡張した球形囊がみら れたてとからも明らかである。したがってての 方法は，極めて短時間で形成された内リンパ水 腫のひとつのモデルであるといえる.

人工内リンパ注入中，注入後共に内・外リン パ圧が同一の変化を示したととは，内リンパ水 腫の形成後のみならず，形成中に押いても内・ 外リンパ圧の間に有意の差が無いととを示して いる。 つまり，ライスネル膜は中央階の体積の 増加に伴って容易に伸展し，乙の際に内リンパ 圧の外リンパ圧に対する有意の上昇を伴わない．

我々はこれまでに外リンパ圧の変化が減衰す ることなく，また時間的に遅れることなく内リ ンパに伝達されるととを報告してきた778)．本 研究では内リンパから外リンパの方向において あ同様に圧の変化が伝達されることが示された.

人工内リンパ注入終了後, 内・外リンパ圧と あに速やかに注入前の值近くまでもどったてと は，注入にともなう内耳液の体積増加が外リン パの蝸牛水管または内耳道経由の脳脊䯣液腔へ の移動によって解消されたためと考えられる.

Tasaki ら ${ }^{11)}$ は $\mathrm{KCl}$ 等張液 $0.015 \mu \mathrm{l}$ を中央 階に注入すると，EP の上昇がみられたと報告 している，我々の実験においては，人工内リン パを中央階に注入した際に $\mathrm{EP}$ の低下がみられ た. この相違の主な原因は, 我々の実験では注 入量が Tasaki らの100倍以上であるため，内 耳骨胞内の一過性の圧の上昇が内耳血流の減少 を来したためと考えている.

てれまでの我々の研究結果 ${ }^{6)}$ ８) と本研究の結 果から，内リンパ水腫に扣いて内リンパ圧が外 リンパ压に比べて現在利用しうる方法で明らか にされるほど有意に上昇しているとは考えにく い.
本研究は厚生省特定疾患前庭機能異常調査研究班の 研究費援助, および文部省科学研究費 No. 63771323 の援助によって行われた。

\section{参考文献}

1) Tonndorf $\mathrm{J}$ : The hearing loss in early cases of endolymphatic hydrops. Ann Otol 66 : 766 784, 1957.

2 ) Tonndorf J : Endolymphatic hydrops; mechanical cause of hearing loss. Arch Otorhinolaryngol 212 : 293 299, 1976.

3) Ito S, Fisch U, Diller $\mathrm{N}$, et al : Endolymphatic pressure in experimental hydrops. Arch Otolaryngol Head Neck Surg 113 : 833 835, 1987.

4 ) Bohmer A and Andrews JC : Maintenance of hydrostatic pressure gradients in the membranous labyrinth. Arch Otorhinolaryngol $246: 65 \sim 66$, 1989.

5 ) Long $\mathrm{CH}$ and Morizono $\mathrm{T}$ : Hydrostatic pressure measurements of endolymph and perilymph in a guinea pig model of endolymphatic hydrops. Otolaryngol Head Neck Surg 96 : 83 95, 1987.

6 ) 竹内俊二, 竹田泰三, 齋藤春雄 : 実験的内リンパ 水腫モルモットの内 ・外リンパ圧差. Equilibrium Res Suppl 5 : 88〜91, 1989.

7 ) 竹内俊二, 竹田泰三, 岸本誠司, 他 : 内・外リン パ圧差について. Equilibrium Res Suppl 4:41〜 44, 1988.

8 ）竹内俊二, 竹田泰三, 齋藤春雄 : 脳奉䯣液腔加圧 時の内・外リンパ圧差. 耳鼻臨床 $83: 789 \sim 792$, 1990.

9) Marcus DC, Rokugo M, Ge X, et al : Response of cochlear potentials to presumed alterations of ionic conductance; endolymphatic perfusion of barium, valinomycin and nystatin. Hear Res 12 : 17 30, 1983.

10) Fernandez $C:$ Dimensions of the cochlea (guinea pig). J Acoust Soc Am 24 : 519 523, 1952.

11) Tasaki I, Davis $H$ and Eldredge DH : Exploration of cochlea potentials in guinea pig with a microelectrode. J Acoust Soc Am 26 : 765 773, 1954.

$\left(\begin{array}{l}\text { 原稿受付 : 平成元年 } 12 \text { 月 } 7 \text { 日 } \\ \text { 原稿採択 : 平成 } 2 \text { 年 } 1 \text { 月 } 9 \text { 日 } \\ \text { 別刷請求先 : 竹内俊二 } \\ \text { 干783 高知県南国市岡豊町小蓮 } \\ \text { 高知医科大学耳鼻咽喉科学教室 }\end{array}\right)$

